Bull. Chem. Soc. Ethiop. 2013, 27(1), 25-34.

Printed in Ethiopia

DOI: http://dx.doi.org/10.4314/bcse.v27i1.3

ISSN 1011-3924

(c) 2013 Chemical Society of Ethiopia

\title{
INVESTIGATION ON PLEUROTUS FERULAE POTENTIAL FOR THE SORPTION OF Pb(II) FROM AQUEOUS SOLUTION
}

\author{
A.O. Adebayo* \\ Department of Chemistry, The Federal University of Technology, PMB 704 Akure, 340001 \\ Ondo State, Nigeria
}

(Received March 3, 2011; revised October 10, 2012)

\begin{abstract}
Pleurotus ferulae obtained from rotten tree was collected, washed, dried, ground and sieved to appropriate particle size. Infra-red spectrometry was used to determine functional groups on the biomass while biosorption of $\mathrm{Pb}$ (II) from aqueous solution was studied using the biomass in a batch system. The effect of $\mathrm{pH}$ (17.5), temperature $\left(30-50{ }^{\circ} \mathrm{C}\right)$, biomass dosage of 0.5-4 $\mathrm{g}$ and initial metal concentration $(20-300 \mathrm{mg} / \mathrm{L}) \mathrm{was}$ studied. Equilibrium, kinetics and thermodynamics consideration were evaluated from the studied parameters to evaluate the adsorption potential of the biomass. The functional groups on the dried P. ferulae were: $-\mathrm{OH},-\mathrm{NH}$, $-\mathrm{COO}^{-}$and $-\mathrm{C}-\mathrm{O}$. In the batch experiments maximum biosorption was observed at initial $\mathrm{pH}$ of 3.0, temperature of $30{ }^{\circ} \mathrm{C}$ and at the initial metal concentration of $100 \mathrm{mg} / \mathrm{L}$. A contact time $20 \mathrm{~min}$ was sufficient for quantitative sorption of lead. It was observed that pseudo second order rate expression fit the experimental data and equilibrium analysis showed that the biosorption process followed Langmuir model. Thermodynamic analysis showed that the process was exothermic and $\Delta \mathrm{G}^{\mathrm{o}}$ was negative showing spontaneity of the process within the studied temperature.
\end{abstract}

KEY WORDS: Biosorption, Pb(II), Pleurotus ferulae, Biomass

\section{INTRODUCTION}

Some industrial processes result in the release of toxic metals into the natural water systems. Ecotoxicological effects of these toxic metals are well understood and have been a global concern. Due to their accumulation through food chain and persistent in nature, it is necessary to remove such metals from wastewater before discharging to the environment [1-4]. Lead has been found in at least 1026 of 1467 National Priorities List sites identified by the US Environmental Protection Agency [5]. Lead is used as an industrial raw material for storage battery manufacturing, printing, pigments, fuels, photographic materials and explosive manufacturing [6]. Perhaps no other metal, not even arsenic, has had its toxicology as extensively studied as has lead [7].

Some of the conventional methods of removing metallic ions from wastewater are chemical precipitation, ion exchange, solvent extraction, adsorption and reverse osmosis techniques [8]. Chemical precipitation, especially as metal hydroxide or sulfide, is widely practiced, having the advantages of simplicity and also employing inexpensive chemicals. However, it is not effective to reduce toxic metal concentration to low level required by water quality standards and generation of a voluminous toxic waste sludge is a major problem encountered [4]. Therefore, in the last few decades, adsorption process has received much interest and become an alternative to conventional precipitation and other techniques, especially for wastewaters that contain low concentrations of metals and its effectiveness [8].

Activated carbon is the most widely used adsorbent in the wastewater treatment. Owing to high-cost of activated carbon, search for the low-cost adsorbents such as biomass wastes, and various biological materials have been receiving much attention. Biomass has been advocated for removal of heavy metals for the following reasons: lightness of the particles, ability to be

*Corresponding author. E-mail: adebayoalbert302@hotmail.com 
pulverized to very small size and hence has a large surface area, in most cases has functional groups that could adsorb metals, low cost, easily available among other properties. Pleurotus ferulae is widely consumed as soup condiment in South-western part of Nigeria because of its high level of protein and other nutritional values. It grows very well on dead decaying tree such as mango trees.

Biomass consists of polysaccharides and proteins which may carry variety of functional groups, such as carboxylate, hydroxyl, sulfate, phosphate and amino groups, which can bind metal ions. The removal of metal ions by such various biomasses has received more attention [9-12]. $P$. ferulae biomass is easily available in substantial quantities and can be easily cultured in substantial amounts using unsophisticated techniques. Therefore, it could be used as an economical tool for the removal or recovery of metal ions from aqueous solutions.

The characteristics of the biosorption behavior are generally analyzed by means of both biosorption kinetics and equilibrium isotherms [13, 14]. The objective of this research was to investigate the removal of $\mathrm{Pb}$ (II) from aqueous solutions by the fungus $P$. ferulae. It is widely available, growing on dead decaying mango tree and some other dead trees; it was chosen as a biosorbent material because of a lack of information on its biosorption abilities. The biosorption capacity was determined using various kinetic models. The well-known equations of Langmuir and Freundlich were used for the equilibrium analysis while the kinetic was analysed by using Lagergren expressions. The effect of biosorbent dosage, initial metal concentration, contact time, temperature and $\mathrm{pH}$ was examined. The thermodynamic parameters were also deduced from the adsorption measurements.

\section{EXPERIMENTAL}

\section{Reagents and equipments}

The reagents used in this study were lead nitrate, nitric acid and sodium hydroxide procured from BDH Chemicals, England; they were all of analytical grade reagents. Atomic absorption spectrophotometer (AAS Alpha 4 model, USA) was used for analysis of the metal ions and Fourier Transformation Infra-Red (FTIR Buck 500M, UK) for determination of functional groups in the adsorbent.

\section{Preparation of $P$. ferulae biosorbent and $\mathrm{Pb}(\mathrm{II})$ solution}

The $P$. ferulae used in this study was collected from an old cocoa farm in Apatapiti area, off Federal University of Technology Akure road Ondo state, Nigeria. The collected material was identified in the Department of Microbiology of the Federal University of Technology, Akure Nigeria. The material was washed with deionised water to remove dirt particles. The washed materials were first air dried and later oven dried at $105^{\circ} \mathrm{C}$ for $48 \mathrm{~h}$. Dry biomass was crushed into powder and sieved to $100 \mu \mathrm{m}$ particle size. The stock solution containing $1000 \mathrm{mg} / \mathrm{L}$ of $\mathrm{Pb}$ (II) was prepared by dissolving $1.599 \mathrm{~g}$ of lead nitrate in $10 \mathrm{~mL}$ of nitric acid and then diluted up to $1000 \mathrm{~mL}$ in a volumetric flask with distilled water. The working solutions were obtained by diluting the lead nitrate stock solution in accurate proportions to different initial concentrations.

\section{Spectrometry determination of the functional groups}

Infra-red analysis of dried $P$. ferulae was determined as follows: $\mathrm{KBr}$ pellet was prepared; the mass proportion of $P$. ferulae biomass/KBr was $1 / 100$. Buck 500M FT-IR system was used for the determination of functional groups of the dried $P$. ferulae as described in operational instruction manual. 


\section{Batch biosorption experimental process}

The experiments were conducted in Erlenmeyer flasks containing appropriate amount of dried $P$. ferulae and $50 \mathrm{~mL}$ of $\mathrm{Pb}$ (II) ion synthetic solutions having different concentrations and $\mathrm{pH}$. At the end of the predetermined contact period, reaction mixtures were filtered and the filtrates were analysed for $\mathrm{Pb}$ (II) by means of atomic absorption spectroscopy and the equilibrium concentration were calculated as follows in equation 1 :

$q=\frac{\left(C_{0}-C_{e}\right) V}{M}$

where $M$ is the biosorbent mass $(\mathrm{g}), q$ the adsorbed metal ion quantity per gram of biosorbent at equilibrium $(\mathrm{mg} / \mathrm{g}), C_{0}$ the initial metal concentration $(\mathrm{mg} / \mathrm{L}), C_{\mathrm{e}}$ the metal concentration at equilibrium $(\mathrm{mg} / \mathrm{L})$ and $V$ is the working solution volume $(\mathrm{mL})$.

\section{RESULTS AND DISCUSSION}

Fourier Transform infrared analysis (FTIR) of dried P. ferulae biomass

It is quite important to determine the functional groups which establish the appropriate properties responsible for the sorption behavior of the biomass. An experiment was conducted using Fourier Transformation infra-red spectroscopy. The FTIR spectrum of the dried P. ferulae biomass was taken to obtain information on the nature of the possible functional groups that could responsible for biomass-metal ions interactions.

The broad stretching absorption band at $3441 \mathrm{~cm}^{-1}$ is assigned to both $-\mathrm{NH}$ and bonded $-\mathrm{OH}$ groups. The band observed at $2926 \mathrm{~cm}^{-1}$ is an indication of symmetric/asymmetric stretching vibration of $-\mathrm{CH}_{3}$ and $-\mathrm{CH}_{2}$ groups and their bending vibrations are 1458 and 1467 $\mathrm{cm}^{-1}$ for dried biomass. Carbonyl stretching band of un-ionized carboxylates was observed at $1792 \mathrm{~cm}^{-1}$. The band at $1647 \mathrm{~cm}^{-1}$ is a consequence of $-\mathrm{C}-\mathrm{O}$ stretching vibration conjugated to a $-\mathrm{NH}$ deformation and is indicative of amide-I band. The other band referred to amide group, which is namely amide-II, is present at $1541 \mathrm{~cm}^{-1}$ assigned to $-\mathrm{NH}$ deformation conjugated to $-\mathrm{C}=\mathrm{N}$ deformation for dried biomass. The $1077 \mathrm{~cm}^{-1}$ band was due to $\mathrm{C}-\mathrm{O}$ stretching of carboxyl groups and the bending vibration band of hydroxyl groups. The functional groups which can adsorb metal ions are of the type $-\mathrm{OH},-\mathrm{NH},-\mathrm{COO}^{-}$and $-\mathrm{C}-\mathrm{O}$ present on the biomass [15].

\section{Effect of contact time and biosorbent dosage on biosorption of $P b(I I)$ using P. ferulae}

The effect of contact time was monitored to attain the maximum $\mathrm{Pb}$ (II) uptake capacity. The contact time was varied from 0 to $60 \mathrm{~min}$ at a fixed predetermined initial $\mathrm{Pb}$ (II) concentration of $100 \mathrm{mg} / \mathrm{L}$ and $30{ }^{\circ} \mathrm{C}$ in $50 \mathrm{~mL}$ solution. The metal biosorption increased rapidly during the first $20 \mathrm{~min}$ and thereafter become very slow as shown in Figure 1. After this equilibrium period, the amount of biosorbed metals ions did not appreciably change with time. A contact time of 20 min was considered to be the optimum and most economic time for subsequent experiments.

The effect of biosorbent dosage was monitored to attain the maximum $\mathrm{Pb}$ (II) uptake capacity. The dosage was varied from 0.5 to $5 \mathrm{~g}$ at a fixed initial $\mathrm{Pb}$ (II) concentration of 100 $\mathrm{mg} / \mathrm{L}$ in $50 \mathrm{~mL}$ of the solution at $30^{\circ} \mathrm{C}$. Each dosage was monitored for a period of one hour and sample was taken at selected time intervals (Figure 2). Equilibrium uptake capacity was found to be increasing with increase in biosorbent dosage and contact time reached a plateau at about $20 \mathrm{~min}$ for the dosage tested. Various reasons could be suggested to explain the increased 
biosorption capacity by increasing biosorbent dosage including availability of more surfaces, electrostatic interactions and competition between binding sites. It appears that biosorbent dosage does not appreciable affect the sorption capacity beyond $3 \mathrm{~g}$. of the biomass. The equilibrium $\mathrm{Pb}$ (II) uptake capacity $(q)$ of $3 \mathrm{~g}$ was found to be almost the same as $5 \mathrm{~g}$ and so $3 \mathrm{~g}$ of biosorbent dosage was taken as optimum value for the subsequent experiments.

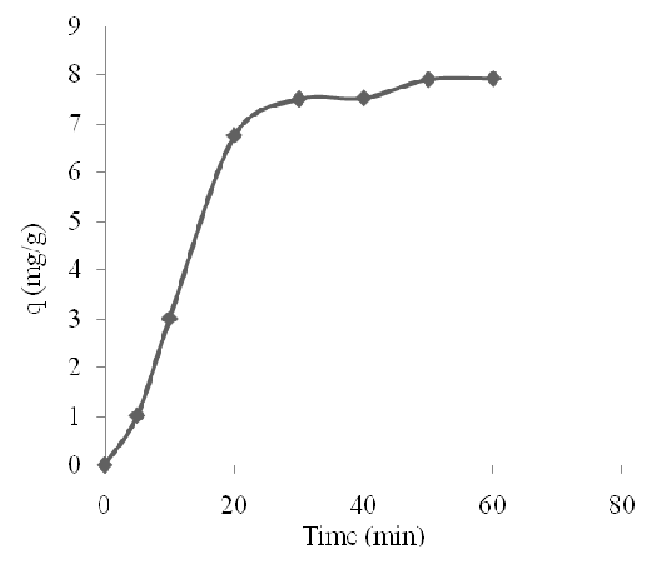

Figure 1. Effect of contact time on biosorption of $\mathrm{Pb}(\mathrm{II})$ using $P$. ferulae.

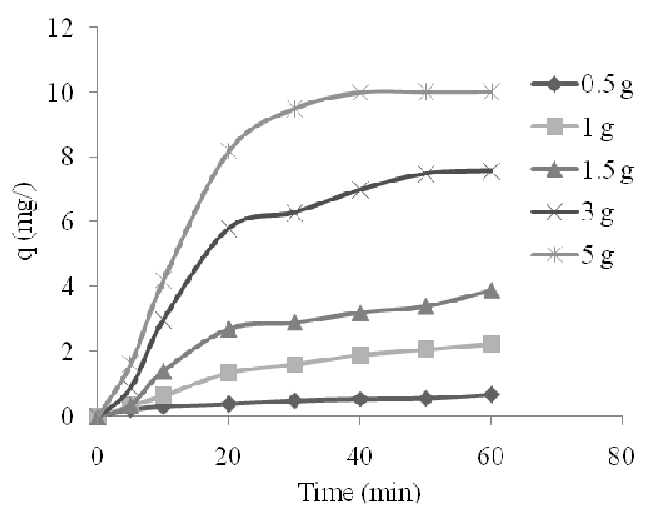

Figure 2. Variation of biosorption capacity with respect to time at different dosage.

Effect of $p H$ and initial metal concentration on biosorption of $P b(I I)$ using P. ferulae

The effects of $\mathrm{pH}$ were investigated in the range of 1 to 7.5 at a constant contact time of 20 min, biosorbent dosage of $3 \mathrm{~g}$, initial metal concentration of $100 \mathrm{mg} / \mathrm{L}$. The biosorption capacity against $\mathrm{pH}$ of the solution was plotted in Figure 3 from which can be observed that uptake of $\mathrm{Pb}$ (II) increases with $\mathrm{pH}$. However two $\mathrm{pH}$ regions were observed, the first region was between in $\mathrm{pH}$ range of 1 to 4.5 in which there was an increase in the uptake from $\mathrm{pH} 1$ to 3 and thereafter a level off was observed till $\mathrm{pH} 4.5$. The second region was observed in the $\mathrm{pH}$ range 4.5 to 7.5 , where a white precipitate in the solution was produced which was most probably due to formation of insoluble $\mathrm{Pb}(\mathrm{OH})_{2}$ with $\mathrm{pK}_{\mathrm{sp}}$ of 14.84 [16]. At $\mathrm{pH}$ between 1 and 4.5, the solution was obviously clear and no precipitate was observed. It could be deduce that true

Bull. Chem. Soc. Ethiop. 2013, 27(1) 
biosorption took place between $\mathrm{pH}$ of 1 and 4.5 whereas at $\mathrm{pH}$ between 4.5 and 7.5 , there was precipitation in which removal of the metal is not really by adsorption alone.

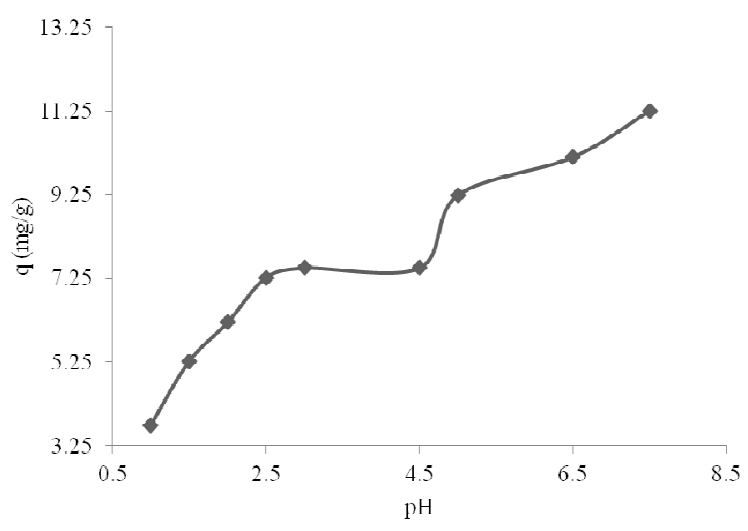

Figure 3. Effect of $\mathrm{pH}$ on biosorption of lead using $P$. ferulae.

The biosorption of $\mathrm{Pb}(\mathrm{II})$ by $P$. ferulae affected by the initial $\mathrm{pH}$ of the metal solution has been argued to be due to ionic attraction between the possible charge on the biomass and the metal ions particularly at much lower $\mathrm{pH}$. Earlier studies on heavy metal biosorption have shown that $\mathrm{pH}$ is one of the important parameters affecting most biosorption processes $[17,18]$. The medium $\mathrm{pH}$ affects the solubility of metal ions and the ionization state of the functional groups like carboxylate, phosphate and amino groups of the biomass. The carboxylate and phosphate groups carry negative charges that allow the biomass components to be potent scavengers of cations. The inconsistency in literature regarding the influence of $\mathrm{pH}$ on biosorption seems to indicate that the way $\mathrm{pH}$ would alter the biosorption of metal ions to biomass varies with the type of biosorbents (biomass) and also the type of adsorbates (metal ions). The biosorption of $\mathrm{Pb}$ (II) at different initial concentration in the range of 20 to $300 \mathrm{mg} / \mathrm{L}$ was conducted using $3 \mathrm{~g} P$. ferulae, at varying contact time, at $30{ }^{\circ} \mathrm{C}$. From Figure 4 , it was observed that the metal uptake capacity increased linearly with time for all studied initial $\mathrm{Pb}(\mathrm{II})$ concentration in the first 20 min and finally attained saturation situation.

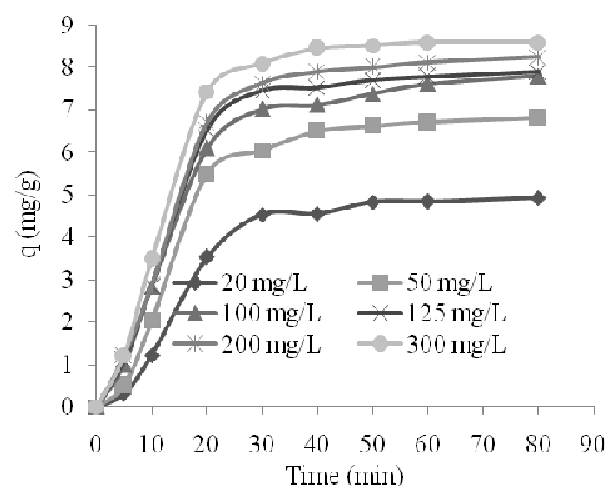

Figure 4. Variation of biosorbent of capacity with time on biosorption of $\mathrm{Pb}$ (II) using P. ferulae at different initial metal concentration.

Bull. Chem. Soc. Ethiop. 2013, 27(1) 
The value of $\mathrm{q}_{\mathrm{e}}$ was observed to increase with the initial metal concentration, for instance at $20 \mathrm{mg} / \mathrm{L} \mathrm{q}$ has a value of $4.65 \mathrm{mg} / \mathrm{g}$ which increases to $7.5 \mathrm{mg} / \mathrm{g}$ at $100 \mathrm{mg} / \mathrm{L}$ of initial $\mathrm{Pb}$ (II) concentration. However above $100 \mathrm{mg} / \mathrm{L} \mathrm{Pb}$ (II) increases in biosorption capacity was less than the lower initial metal concentration. The biosorption of the metal with the increase of initial metal concentration could be attributed to higher probability of interaction between metal ions and biosorbent. Furthermore, higher initial metal concentration provides an increased driving force to overcome all mass transfer resistance of metals between aqueous and solid phases thereby accelerate probable collision between metal ion and sorbents which results in higher metal uptake [16]. A similar type of pattern was previously reported by Ho and McKay for the removal of lead [19].

\section{Effect of temperature and thermodynamic consideration of biosorption of $\mathrm{Pb}(\mathrm{II})$ on $\mathrm{P}$. ferulae}

The effect of temperature on the equilibrium sorption capacity of dried $P$. ferulae biomass was investigated in the temperature range of $30-50{ }^{\circ} \mathrm{C}$. It was observe that biosorption capacity of the biomass decrease with increasing temperature. The reduction of the metal removal in the interval of temperature $30-50{ }^{\circ} \mathrm{C}$ means that the process of lead sorption by $P$. ferulae is exothermic as it is the case for the majority of gas adsorption processes. Similar results have been reported for the sorption of $\mathrm{Pb}$ (II) by Cephalosporium aphidicola from aqueous solution at temperature between $20-40{ }^{\circ} \mathrm{C}$ [20] and biosorption of $\mathrm{Pb}(\mathrm{II})$ and $\mathrm{Cu}(\mathrm{II})$ with dried activated sludge [21].

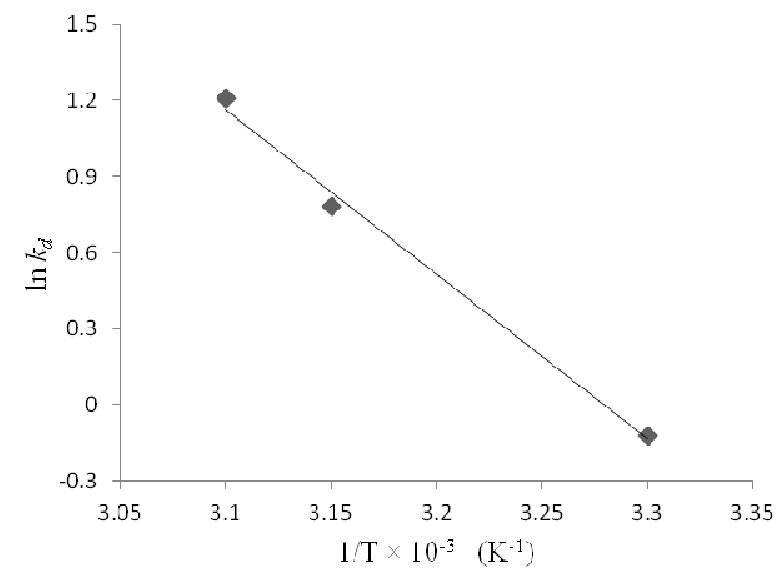

Figure 5. Plot of $\ln k_{d}$ versus $1 / \mathrm{T}$ on sorption of $\mathrm{Pb}(\mathrm{II})$ with $P$. ferulae.

The effect of temperature conducted in the range of $30-50{ }^{\circ} \mathrm{C}$ was used to determine some important thermodynamic parameters on the biosorption of $\mathrm{Pb}$ (II). The values of equilibrium constants $\left(K_{d}\right)$ at 30,40 and $50{ }^{\circ} \mathrm{C}$ were calculated from the relation in equation 2 :

$k_{d}=\frac{C_{e}}{C_{s}}$

where $C_{e}$ and $C_{s}$ are the equilibrium concentrations $(\mathrm{mg} / \mathrm{L})$ of $\mathrm{Pb}$ (II) on the biosorbent and in solution, respectively.

$\Delta G^{o}=-R T \ln k_{d}$

where $T$ is the absolute temperature, $R$ is gas constant and $\Delta G^{\circ}$ is the standard free energy change. 
The values of enthalpy change $\left(\Delta H^{\circ}\right)$ and entropy change $\left(\Delta S^{\circ}\right)$ were calculated from the following relation:

$\ln k_{\mathrm{d}}=\frac{\Delta S^{o}}{R}-\frac{\Delta H^{o}}{R T}$

$\Delta S^{\mathrm{o}}$ and $\Delta H^{\mathrm{o}}$ were calculated from the slope and intercept of Van't Hoff plot of $\ln k_{d}$ versus $1 / T$ (Figure 5). Table 1 shows the values of $k_{d}, \Delta H^{\circ}, \Delta S^{\circ}$ and $\Delta G^{\circ}$. Thermodynamic parameters are quite useful for evaluation of feasibility of any process.

The negative values of $\Delta G^{\mathrm{o}}$ show that the process is spontaneous and spontaneity decreases with increase in temperature within the studied range. The positive value of $\Delta S^{\circ}$ suggests an increase randomness at the solid-liquid interface during biosorption. The negative values of $\Delta H^{\circ}$ confirm that the process under studies is exothermic while obtained value $k_{d}$ indicate favoured process at $303 \mathrm{~K}$ but decrease with temperature.

Table 1. Thermodynamic parameters for biosorption of $\mathrm{Pb}(\mathrm{II})$ on $P$. ferulae.

\begin{tabular}{|c|c|c|c|c|}
\hline Temperature, $\mathrm{K}$ & $k_{d}$ & $\Delta \mathrm{G}^{\mathrm{o}}, \mathrm{kJ} / \mathrm{mol}$ & $\Delta \mathrm{H}^{\mathrm{o}}, \mathrm{kJ} / \mathrm{mol}$ & $\Delta \mathrm{S}^{\mathrm{o}}, \mathrm{kJ} / \mathrm{mol}$ \\
\hline 303 & 3.35 & -0.3045 & -0.0552 & 0.1712 \\
\hline 318 & 2.33 & -0.2236 & -0.0552 & 0.1712 \\
\hline 323 & 0.89 & -0.0313 & -0.0552 & 0.1712 \\
\hline
\end{tabular}

Biosorption kinetic of $\mathrm{Pb}(\mathrm{II})$ on $\mathrm{P}$. ferulae

The biosorption mechanism and potential rate controlling steps have been investigated by using the pseudo-first and pseudo-second order kinetic models. The pseudo-first order [13] rate expression of Lagergren is

$\frac{d q}{d t}=k_{1, a d}\left(q_{e}-q\right)$

where $q$ is the amount of metal adsorbed on the biosorbent at time $t$ and $k 1$, ad $\left(\mathrm{min}^{-1}\right)$ is the rate constant for pseudo first order biosorption. The integral form of equation 5 is

$\ln \left(q_{e}-q\right)=\ln q_{e}-k_{1, a d} t$

A linear fit of $\ln \left(q_{\mathrm{e}}-q\right)$ versus $t$ shows the applicability of this kinetic model. Expression for the pseudo-second order kinetic model is [14]

$\frac{d q}{d t}=k_{2, a d}\left(q_{e}-q\right)^{2}$

where $k_{2, \text { ad }}(\mathrm{g} / \mathrm{mg} \min )$ is the rate constant of the pseudo-second order biosorption. The integrated linear form of equation 7 is

$\frac{t}{q}=\frac{1}{k_{2, a d} q_{e}^{2}}+\frac{1}{q_{e}} t$

If the experimental data fits the plot of $t / q$ versus $t$ as linear relationship, the pseudo-second order kinetic model is valid.

From the slopes and intercepts of plots of $\log \left(q_{\mathrm{e}}-q\right)$ vs. $t$ obtained for the removal initial metal concentrations using $P$. ferulae, the pseudo-first-order rate constants $\left(k_{1, \text { ad }}\right)$ and theoretical $q_{\text {eq,al }}$ values were determined. Also, $t / q$ was plotted against $t$ for removal of metal using $P$.

Bull. Chem. Soc. Ethiop. 2013, 27(1) 
ferulae. The Pseudo-second-order biosorption rate constant $\left(k_{2, \mathrm{ad}}\right)$ and theoretical $q_{\mathrm{e}}$ values were determined from the slope and intercept of the plots. The values of the parameters $\left(k_{2, \text { ad }}\right), q_{\mathrm{e}}$ calculated and $q_{\mathrm{e}}$ experimental together with correlation coefficients are presented in Table 2 .

The linearized form of the pseudo-first and pseudo-second order kinetic model at different initial metal concentrations for the period of $60 \mathrm{~min}$ was analysed. The correlation coefficients of the Pseudo-first-order kinetic model obtained for metal using $P$. ferulae were found to be less when compared to the pseudo-second-order kinetic model studied in the present investigation (Table 2).

Table 2. The pseudo-first and second order rate constants, $\mathrm{r}^{2}$, calculated and experimental $q_{\mathrm{eq}}$ values for the biosorption of $\mathrm{Pb}(\mathrm{II})$ using $P$. ferulae.

\begin{tabular}{|c|c|c|c|c|c|c|c|}
\hline \multicolumn{2}{|c|}{} & \multicolumn{3}{c|}{ Pseudo-first order } & \multicolumn{3}{c|}{ Pseudo-second order } \\
\hline $\mathrm{C}_{\mathrm{o}}(\mathrm{mg} / \mathrm{L})$ & $\mathrm{q}_{\mathrm{e}, \exp }(\mathrm{mg} / \mathrm{g})$ & $\mathrm{q}_{\mathrm{e}, \mathrm{cal}}(\mathrm{mg} / \mathrm{g})$ & $k_{l}(1 / \mathrm{min})$ & $\mathrm{r}^{2}$ & $\mathrm{q}_{\mathrm{e}, \text { cal }}(\mathrm{g} / \mathrm{g})$ & $k_{2}(\mathrm{~g} / \mathrm{mg}$.min $)$ & $\mathrm{r}^{2}$ \\
\hline 20 & 4.65 & 1.79 & 0.068 & 0.971 & 2.72 & 0.166 & 0.992 \\
\hline 50 & 6.31 & 2.17 & 0.082 & 0.990 & 5.89 & 0.116 & 0.998 \\
\hline 100 & 7.51 & 2.05 & 0.069 & 0.963 & 7.54 & 0.118 & 1.000 \\
\hline 125 & 7.80 & 2.29 & 0.107 & 0.972 & 7.07 & 0.119 & 0.999 \\
\hline 200 & 7.95 & 2.07 & 0.084 & 0.935 & 7.39 & 0.116 & 0.999 \\
\hline 300 & 8.10 & 2.03 & 0.084 & 0.934 & 8.03 & 0.115 & 0.999 \\
\hline
\end{tabular}

\section{Biosorption equilibrium of $\mathrm{Pb}(\mathrm{II})$ on $\mathrm{P}$. ferulae}

The biosorptive of metal can be quantitatively evaluated by experimental equilibrium isotherms. The graphical expression of isotherm is a plot of the metal uptake by the per unit weight of biosorbent against the residual metal ion concentration in the biosorption medium. There are two widely accepted and easily linearized adsorption isotherm models used in the literature, which are namely Freundlich and Langmuir models.

The Freundlich model is based on the relationship between the metal uptake capacity " $q$ " $(\mathrm{mg} / \mathrm{g})$ of biomass and the equilibrium metal ion concentration " $C_{\mathrm{e}}$ " $(\mathrm{mg} / \mathrm{L})$. The general Freundlich equation is as follows:

$q=k_{f} C_{e}^{1 / n}$

And the linearized form of the model is

$\ln q_{e}=\ln k_{f}+\frac{1}{n} \ln C_{e}$

where intercept, $\ln k_{f}$, is a measure of adsorbent capacity, and the slope, $1 / n$, is the intensity of adsorption.

The general Langmuir equation is commonly presented as

$q_{e}=\frac{Q_{o} b C_{e}}{1+b C_{e}}$

and the equation may be linearized as follows:

$\frac{C_{e}}{q_{e}}=\frac{1}{Q_{o} b}+\frac{C_{e}}{Q_{o}}$

where $q_{\mathrm{e}}$ is the amount of metal ion removed $(\mathrm{mg} / \mathrm{g}), C_{\mathrm{e}}$ the equilibrium concentration of the metal ions $(\mathrm{mg} / \mathrm{L}), Q_{\mathrm{o}}$ and $b$ are the Langmuir constants related to adsorption capacity and affinity, respectively. Experimental data fitted to the both Freundlich and Langmuir isotherms. The correlation coefficients of Langmuir adsorption isotherm showed that the Langmuir 
isotherm yielded the best fitted to the experimental data. Langmuir equation provides a best correlation with the experimental data. The necessary equilibrium constants were calculated from the corresponding plots (figures not shown) for the biosorption of $\mathrm{Pb}$ (II) on the biosorbent and the results are presented in Table 3 . Therefore, biosorption process in this study may be interpreted as monolayer adsorption. The values of $b$ indicate the affinity of biosorbent to investigated metals and imply strong binding of metal ions.

\section{Effect of interfering cations on biosorption of Pb(II) using P. ferulae}

Waste water rarely contain single metals, it is usually associated with many metals that may have similar chemistry. For instance $\mathrm{Pb}$ (II) is usually found in association with most of divalent metals. $\mathrm{Cd}(\mathrm{II})$ and $\mathrm{Zn}$ (II) has been found in many cases associated with lead, so their interfering effect was investigated by finding the adsorption efficiency on $50 \mathrm{mg} / \mathrm{L}$ of lead at $\mathrm{pH} 3.0$. The effect of increasing concentration of interfering metals is shown in Figure 6. It can be observed that only small decrease of less $1 \%$ is observed on studied metals.

Table 3. Langmuir and Freundlich constants from $\mathrm{Pb}(\mathrm{II})$ isotherms.

\begin{tabular}{|c|c|c|c|c|c|c|}
\hline & \multicolumn{3}{|c|}{ Langmuir } & \multicolumn{2}{c|}{ Freundlich } \\
\hline $\mathrm{C}_{\mathrm{o}}(\mathrm{mg} / \mathrm{L})$ & $\mathrm{q}_{\max }(\mathrm{mg} / \mathrm{g})$ & $b(\mathrm{~g} / \mathrm{mg} \cdot \mathrm{min})$ & $\mathrm{r}^{2}$ & $k_{f}$ & $1 / \mathrm{n}$ & $\mathrm{r}^{2}$ \\
\hline 20 & 2.79 & 5.68 & 0.992 & 0.72 & 0.166 & 0.912 \\
\hline 50 & 5.17 & 5.82 & 0.990 & 0.89 & 0.116 & 0.928 \\
\hline 100 & 7.54 & 5.69 & 1.000 & 1.54 & 0.118 & 0.870 \\
\hline 200 & 7.37 & 5.84 & 0.999 & 1.39 & 0.116 & 0.909 \\
\hline 300 & 8.03 & 5.84 & 0.999 & 1.03 & 0.115 & 0.919 \\
\hline
\end{tabular}

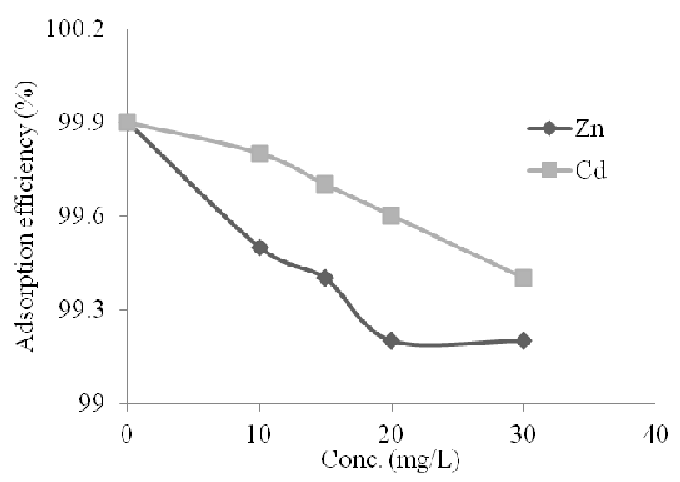

Figure 6. Effect of $\mathrm{Cd}(\mathrm{II})$ and $\mathrm{Zn}$ (II) competition on adsorption of $\mathrm{Pb}$ (II) on P. ferulae.

\section{CONCLUSION}

In this study, a dried powdered Pleurotus ferulae biomass was studied for the sorption of $\mathrm{Pb}$ (II) from simulated solution. The possible functional groups on the dried $P$. ferulae are $-\mathrm{OH},-\mathrm{NH}$, $-\mathrm{COO}^{-}$and $-\mathrm{C}-\mathrm{O}$, thereafter the simulated solution was studied by investigating the effect of contact time, biosorbent dosage, initial metal concentration, initial $\mathrm{pH}$ and temperature. From these variables, kinetic, equilibrium and thermodynamic parameters were determined and the following conclusions were drawn. There was rapid biosorption of $\mathrm{Pb}$ (II) within the first 20 min with biosorption capacity of $6.5 \mathrm{mg} / \mathrm{g}$ and thereafter became very slow. There was increase in biosorbent dosage from 0.5 to $3 \mathrm{~g}$ and thereafter does not show appreciable sorption. There was increase in biosorption with increase in $\mathrm{pH}$ up to 3 and thereafter reaches a plateau. Though 
removal of $\mathrm{Pb}$ (II) was still observed up to the value of 7.5 , but this was strongly assumed due to precipitation. Rapid biosorption with initial of $\mathrm{Pb}(\mathrm{II})$ concentration up to $100 \mathrm{mg} / \mathrm{L}$ was observed and thereafter does not show appreciable sorption. Increase in temperature lead to decrease in sorption $\mathrm{Pb}(\mathrm{II})$ on to $P$. ferulae biomass indicating exothermic process. Kinetic analysis using rate expressions of Lagergren show that the process is pseudo-second order reaction model. Initial biosorption rate increases with the increase in initial $\mathrm{Pb}$ (II) concentration and decrease with increase in temperature. Equilibrium analysis using Freundlich and Langmuir models shows that the biosorption process is Langmuir model. Thermodynamics consideration shows that equilibrium constant $\left(K_{d}\right)$ decrease with temperature, Gibb's free energy $\left(\Delta G^{0}\right)$ decrease with increase in temperature showing that biosorption of $\mathrm{Pb}$ (II) using $P$. ferulae is better performed at $30{ }^{\circ} \mathrm{C}$. The results suggest that $P$. ferulae is a potential adsorbing media for lead in the treatment of wastewater. The effect of $\mathrm{Cd}$ (II) and $\mathrm{Zn}$ (II) shows minimal effect as a competing cations.

\section{ACKNOWLEDGEMENTS}

The contributions of the following people are highly acknowledged: Prof. K.A. Onifade and Dr. (Mrs.) B.J. Akinyele both of Microbiology Department of the Federal University of Technology, Akure for identification of the P. ferulae.

\section{REFERENCES}

1. Agency for Toxic Substances and Disease Registry (ATSDR) Factsheet, http://atsdr1.atsdr.cdc.gov:8080/tfacts5.html; accessed in 1993.

2. Cadmium: Market Update, Analysis and Outlook, Roskill Information Services: London; 1995.

3. Kapoor, A.; Viraraghavan, T. Bioresour. Technol. 1995 53, 195.

5. Faust, S.D.; Aly, O.M. Adsorption Processes for Water Treatment, Butterworth Publishers: Boston; 1987; p 207.

4. Sheng, P.X.; Ting, Y.P.; Chen, J.P.; Hong, L. J. Colloid Interface Sci. 2004, 275, 131.

6. Bang, S.W.; Clark, D.S.; Keasling, J.D. Biotechnol. Lett. 2000, 22, 133.

7. Zafar, S.; Aqil, F.; Ahmad, I. Biores. Technol. 2007, 98, 255.

8. Al-Asheh, S.; Duvnjak, Z. Sep. Sci. Technol. 1998, 33, 1303.

9. Sar1, A.; Tuzen, M. J. Hazard. Mater. 2008, 157, 448.

10. Schiewer, S.; Patil, S.B. J. Hazard. Mater. 2008, 157, 8.

11. Krishnani, K.K.; Christodoulatos, X.M.C.; Boddu, V.M. J. Hazard. Mater. 2008, 153, 1222.

12. Lodeiro, P.; Barriada, J.L.; Herrero, R.; Sastre de Vicente, M.E. Environ. Pollut. 2006, 142, 264.

13. Freitas, O.M.M.; Martins, R.J.E.; Delerue-Matos, C.M.; Boaventura, R.A.R. J. Hazard. Mater. 2008, 153, 493.

14. Herrero, R.; Cordero, B. Lodeiro, P.; Rey-Castro, C.; Sastre de Vicente, M.E; Mar. Chem. 2006, 99, 106.

15. Xuejiang, W.; Ling, C.; Siqing, X.; Jianfu, Z.; Chovelon, J.; Renault, N. J. Miner. Engin. 2006, 19, 968.

16. Dean, J.A. Lange's Handbook of Chemistry, 15th ed., McGraw-Hill: New York; 1999; p 1121.

17. Bulut, Y.; Baysal, Z. J. Environ. Manage. 2006, 78, 107.

18. Sittig, M. Pollutant Removal Handbook, Noyes Data Corporation: England; 1973; p 107.

19. Tunali, S.; Akar, T.; zcan, A.S.O.; Kiran, I.; Zcan, A.O. Sep. Purif. Technol. 2006, 47, 105.

20. Katsumata, H.; Kaneco, S.; Inomata, K.; Itoh, K.; Funasaks, K.; Masumaya, K.; Suzuki, T.; Ohta, K J. Environ. Manage. 2003, 69, 187. 